\title{
Gene Deletions Correlate with the Development of Alloantibodies in von Willebrand Disease
}

\author{
Beverley B. Shelton-Inloes, ${ }^{*}$ Farid F. Chehab, ${ }^{\ddagger}$ Pier M. Mannucci, ${ }^{3}$ Augusto B. Federici, and J. Evan Sadler* \\ ${ }^{*}$ Howard Hughes Medical Institute, Division of Hematology-Oncology, Departments of Medicine and Biological Chemistry, Washington \\ University, St. Louis, Missouri 63110; ${ }^{\ddagger}$ Howard Hughes Medical Institute, Department of Medicine, University of California, San \\ Francisco, California 94143; and ${ }^{\S}$ A. Bianchi Bonomi Hemophilia and Thrombosis Center and the Institute of Internal Medicine, \\ University and Maggiore Hospital, Milano, Italy
}

\begin{abstract}
Among all patients with von Willebrand disease (vWD), alloantibodies to von Willebrand factor (vWF) have been described only in severe vWD (type III). The relationship between the development of alloantibodies and the nature of the genetic lesion in $\mathrm{VWD}$ is not known. In hemophilia $B$, large deletions within the factor IX gene appear to correlate with the occurrence of alloantibodies, whereas in hemophilia $A$ no such correlation is apparent. We have studied 19 patients with severe recessive $\mathrm{VWD}$ (type III) and 19 with autosomal dominant vWD (type I) by Southern blotting with probes encompassing the full 9 kilobases (kb) of the vWF cDNA. Two apparently unrelated patients were shown to have large deletions within the vWF gene. Both patients had severe vWD (type III) and were the only patients among those studied that had inhibitory alloantibodies to VWF. The extent of deletion was similar in both patients, corresponding to at least the 3'-7.4 kb of the vWF cDNA. The deletion in each patient was estimated to exceed $110 \mathrm{~kb}$. In addition, the localization of the vWF gene to chromosome 12 was confirmed, and a homologous sequence on chromosome 22 was identified.
\end{abstract}

\section{Introduction}

Von Willebrand factor (vWF) ${ }^{1}$ is a complex glycoprotein that is required for platelet adhesion to sites of vascular damage (1) and for normal factor VIII survival in circulation (2). Human vWF is composed of identical subunits of $M_{\mathrm{r}} \sim 250,000$ that are assembled into multimers ranging from dimers to species with $M_{\mathrm{r}}>10,000,000$ (reviewed in 3 ). It is synthesized in endothelial cells $(4,5)$ and megakaryocytes $(6)$ and is found in platelet $\alpha$-granules and subendothelial connective tissue as well as in plasma (1). The sequence of the vWF precursor has been determined by protein (7) and complementary DNA (cDNA) sequencing (8-15). The messenger RNA (mRNA) is $\sim 9.0$ kil-

Portions of this work have been presented in abstract form (1986. Blood. 68[Suppl. 1]:338a) and presented at the annual meeting of the American Society of Hematology, San Francisco, CA, December 1986.

Address correspondence to J. Evan Sadler, 660 S. Euclid, Box 8045, Washington University School of Medicine, St. Louis, MO 63110.

Received for publication 18 September 1986.

1. Abbreviations used in this paper: vWAgII, von Willebrand antigen II; vWD, von Willebrand disease; vWF, von Willebrand factor.

J. Clin. Invest.

(c) The American Society for Clinical Investigation, Inc.

0021-9738/87/05/1459/07 \$1.00

Volume 79, May 1987, 1459-1465 obases $(\mathrm{kb})$ in length and contains an open reading frame of 8,439 nucleotides, encoding a precursor of 2,813 amino acids. The precursor has a cleavable signal peptide of 22 amino acids, followed by an unusually long propeptide of 741 amino acids that is identical to von Willebrand antigen II, a distinct plasma protein of unknown function (13-15). The mature vWF subunit consists of 2,050 amino acids, and the protein sequence contains four types of repeated domains indicating a complex evolutionary history $(8,12,14)$. The vWF gene has been localized to human chromosome $12_{\text {p12-pter }}(9,11)$.

Von Willebrand disease (vWD) is caused by functional deficiency of vWF and is probably the most common inherited bleeding disorder of man, with a prevalence of at least 125 per million if all degrees of severity are included. The disorder exhibits both genotypic and phenotypic heterogeneity. vWD is usually inherited as an autosomal dominant trait and most such patients appear to have a quantitative deficiency of vWF (vWD type I). However, $\sim 25 \%$ of patients synthesize a qualitatively abnormal protein. Severe autosomal recessive vWD (type III) is much less common, affecting only $0.5-3$ per million, and is characterized by the absence of detectable vWF antigen and activity (1). These severely affected individuals appear to be homozygous or doubly heterozygous for a null vWF allele.

Antibodies to transfused vWF are uncommon in vWD, and have only been described in vWD type III. Only 16 such patients from 13 families have been reported (reviewed in 16). In part this may reflect the rarity of severe vWD. During a survey of vWD in Western Europe and Israel, 8 patients were identified with antibodies to vWF among 106 patients with severe vWD, for a prevalence of $7.5 \%$ (16). This is similar to the $11-15 \%$ prevalence of antifactor VIII antibodies in severe hemophilia A, or the $7-10 \%$ prevalence of antifactor IX in severe hemophilia $B$ (reviewed in 17). The relationship between alterations in gene structure and the development of antibodies to the gene product is not completely understood. Alloantibodies to factor IX have been reported in eight hemophilia $B$ patients with gene deletions (18-21) but in no patients with point mutations. In contrast, antibodies to factor VIII have not been observed consistently in hemophilia A patients with gene deletions, and inhibitory alloantibodies have been found in patients with point mutations $(22,23)$.

In this paper we report that two unrelated patients with severe recessive vWD (type III) and alloantibodies to vWF were found to have large deletions in the vWF gene. A total of 19 patients with autosomal dominant vWD (type I) and 17 additional patients with recessive vWD (type III) did not have detectable deletions in the VWF gene, and none of these patients had antibodies to vWF. The localization of the vWF gene to human chromosome 12 was confirmed, and in addition a homologous sequence was detected on human chromosome 22. 


\section{Methods}

Materials. Restriction endonucleases were obtained from Bethesda Research Laboratories, Gaithersburg, MD, and New England Biolabs, Beverly, MA. The large fragment of $E$. coli DNA polymerase I (Klenow fragment) was from Bethesda Research Laboratories. Nylon membranes (GeneScreen Plus) and $\left[\gamma{ }^{32} \mathrm{P}\right] \mathrm{dCTP}$ were obtained from New England Nuclear (Boston, MA). Nitrocellulose membranes were from Schleicher and Schuell (Keene, NH).

cDNA probes. CDNA inserts were subcloned in pUC18 or M13mp18 and propogated in E. coli JM103 or JM109 (24). Restriction fragments were prepared using the appropriate enzymes according to the recommendations of the supplier and isolated by polyacrylamide gel electrophoresis and electroelution (25). Probe I is a 3.0-kb (linker) Eco RIBam $\mathrm{HI}$ fragment derived from cDNA isolate $\lambda$ HvWF5 (15). It contains $\sim 240$ basepairs (bp) of 5'-noncoding sequence and encodes a 22-residue signal peptide, 741 residues of the von Willebrand antigen II propeptide (vWAgII), and the amino-terminal 143 amino acids of the mature vWf subunit. Certain subfragments of probe I were prepared by further digestion with Nco I. Probe IA is a 1.6-kb (linker) Eco RI-Nco I fragment of $\lambda H v W F 5$ with 3'-terminus at the codon for residue 443 of vWAgII. Probe IB is a 0.9-kb Nco I-Nco I fragment encoding residues 444-741 of vWAgII and residues 1-6 of the mature vWF subunit. Probe IC is the 404-bp insert of cDNA isolate $\lambda$ HvWF1 (8) and corresponds to the carboxyterminal 24 amino acids of vWAgII and 110 amino acids of the mature vWF subunit. Probe II is a 1.2-kb Bam HI-Fsp I fragment derived from $\lambda H v W F 4$ and corresponds to amino acids 144-544 of vWF (12). Probe III is a $2.8-\mathrm{kb}$ Fsp I-Sac I fragment of $\lambda \mathrm{HvWF} 3$ that encodes amino acids 544-1461 of vWF (8). Probe IV is a 1.8-kb Sac I-Sac I fragment of $\lambda \mathrm{HvWF} 3$ that encodes amino acids 1462-2050 (carboxy-terminus) of vWF. Probe IV also contains 127 out of the total 137 nucleotides of 3 '-noncoding sequence (8). Probes were labeled either by nick translation (25) or with Klenow fragment (26) to a specific activity of $>10^{8}$ $\mathrm{cpm} / \mu \mathrm{g}$.

Chromosome localization of the $v W F$ gene and related sequences. Human chromosome suspensions were prepared from a lymphocyte cell line in Tris-spermine buffer and stained with DIPI and chromomycin A3 (27). 30,000 chromosomes of each type were sorted using a duallaser fluorescence-activated cell sorter and spotted onto a nitrocellulose filter. The filters were processed and hybridized to cDNA probes, and signals were detected by autoradiography as previously described (27). The final stringent washing condition was $0.1 \times$ standard saline citrate (SSC), $0.1 \%$ (wt/vol) sodium dodecyl sulfate (SDS), for $45 \mathrm{~min}$ at $65^{\circ} \mathrm{C}$ $(1 \times \mathrm{SSC}$ is $0.15 \mathrm{M} \mathrm{NaCl}, 0.015 \mathrm{M}$ sodium citrate, $\mathrm{pH} 7.0)$.

Sufficient human chromosome 22 was purified as described in the preceeding paragraph for restriction enzyme digestion and Southern blotting. DNA was also prepared from a mouse-human hybrid cell line containing human chromosome 12 but not chromosomes $9-11$ or 22 , and also from a mouse-human hybrid cell line containing human chromosome 22. Aliquots of DNA were digested with restriction enzymes as indicated in specific figure legends, electrophoresed on $1 \%$ agarose gels in $1 \times$ Tris-acetate-EDTA buffer (TAE), transfered to nitrocellulose filters, prehybridized, and hybridized to cDNA probes (25). The final stringent washing condition was $0.2 \times \mathrm{SSC}$ at $65^{\circ} \mathrm{C}$ for $30 \mathrm{~min}$. Blots were exposed to Kodak XAR-5 film with two intensifying screens (Dupont Cronex Lightning Plus) at $-80^{\circ} \mathrm{C}$ for $1-7 \mathrm{~d}$.

Southern blotting of patient DNA samples. Blood was obtained by venipuncture, anticoagulated with acid citrate dextrose, and stored at $-20^{\circ} \mathrm{C}$. DNA was prepared from $30-50 \mathrm{ml}$ frozen peripheral blood (28) and aliquots were digested with Eco RI. Digested DNA was extracted with phenol/chloroform, precipitated with ethanol, dissolved in $10 \mathrm{mM}$ Tris-Cl, pH 8.0, $1 \mathrm{mM}$ EDTA, and quantitated by fluorometric assay $(29,30)$. 7-10 $\mu \mathrm{g}$ was electrophoresed on a $1 \%$ agarose gel in $1 \times$ Trisborate-EDTA buffer (TBE) (25) and transferred to GeneScreen Plus under alkaline conditions in $0.4 \mathrm{M} \mathrm{NaOH}, 0.6 \mathrm{M} \mathrm{NaCl}$ (31). The membrane was neutralized for $15 \mathrm{~min}$ in $0.5 \mathrm{M}$ Tris- $\mathrm{Cl}, \mathrm{pH} 7,1 \mathrm{M} \mathrm{NaCl}$, and dried at $55^{\circ} \mathrm{C}$ for $20 \mathrm{~min}$. The membranes were prehybridized in $50 \mathrm{mM}$ Tris-
$\mathrm{Cl}, \mathrm{pH} 7.5,1 \mathrm{M} \mathrm{NaCl}, 200 \mu \mathrm{g} / \mathrm{ml}$ yeast transfer RNA for $30 \mathrm{~min}$ at $65^{\circ} \mathrm{C}$. The prehybridization solution was then supplemented with $10 \%$ dextran sulphate, $1 \%$ SDS, $200 \mu \mathrm{g} / \mathrm{ml}$ salmon sperm DNA, and ${ }^{32} \mathrm{P}$ labeled probe at $10^{6} \mathrm{cpm} / \mathrm{ml}$. Filters were subjected to a final stringent wash in $0.2 \times \mathrm{SSC}, 1 \% \mathrm{SDS}$ for $15-60 \mathrm{~min}$ at $65^{\circ} \mathrm{C}$, and rinsed in 0.1 $\times$ SSC. The wet blots were wrapped in plastic wrap and exposed to XAR-5 film (Eastman Kodak Co., Rochester, NY) at $-70^{\circ} \mathrm{C}$ with one intensifying screen. The autoradiographs were developed after 3-10 d of exposure.

\section{Results}

cDNA probes for human $v W F$. Nonoverlapping cDNA probes were prepared that span the full length of the vWF mRNA (Fig. 1). Four probes (I-IV) were used to screen DNA from patients with vWD for evidence of gene deletion and restriction fragment length polymorphism. Subfragments of probe I (IA, B, and C) were prepared to better define the 5 -extent of gene deletions in two patients, and to clarify the chromosomal origin of specific bands detected in Southern blots of patient and control DNA.

Localization of the $v W F$ gene to chromosome 12 and related sequences to chromosome 22. The characterization of the vWF gene by Southern blotting is complicated by the presence of at least two loci in the human genome that hybridize to segments of the vWF cDNA. Restriction fragments of $3.0 \mathrm{~kb}$ or less from the 3 '-end of the cDNA have been used previously to localize the vWF gene to human chromosome $12(9,11)$. This localization was reexamined using probes spanning the full length of the vWF cDNA. Human chromosomes labeled with intercalating dyes were sorted with a fluorescence-activated cell sorter, yielding homogeneous preparations of all human chromosomes except for chromosomes 9-12 and 14-15, which were isolated as mixtures. Probes from the 5'-end (probe IC) and 3'-end of the cDNA (probe IV, Fig. 1) were shown to hybridize only to chromosomes 9-12 (Fig. 2, probes IC and IV). Probe III hybridized to the chromosome 9-12 spot, but also hybridized to chromosome 22 under conditions of very high stringency (Fig. 2, probe III). The remaining autosomes and both sex chromosomes were negative. In addition, probe II hybridized to both the chromosome 9-12 and chromosome 22 spots (data not shown). Thus, restriction fragments from the center of the vWF cDNA (probes II and III) were not specific for the vWF locus on chromosome 12.

The hybridization to the chromosome 9-12 spot (Fig. 2) was shown to be due to the chromosome 12 content of that DNA by the use of a mouse-human hybrid cell line containing human

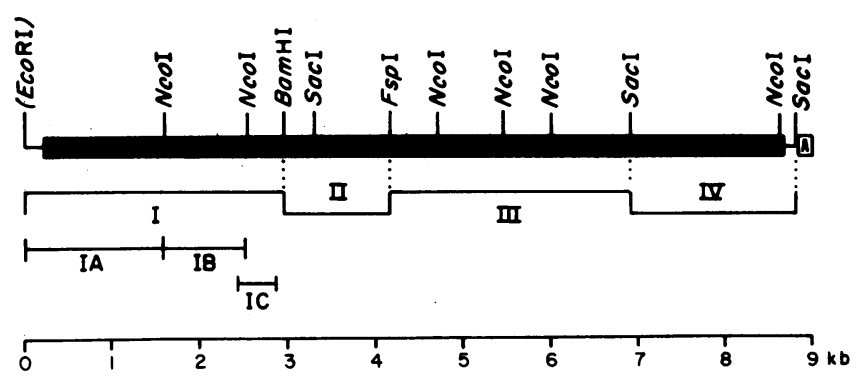

Figure 1. Partial restriction map of human vWF cDNA identifying the location of probes used for Southern blotting. Only restriction sites used in making probes are identified. Coding sequence is represented by the solid bar, and the segment at the 3 '-terminus $A$ represents the poly(A) tail. Fragments represented in CDNA probes are indicated by the labels I, IA, IB, IC, II, III, and IV. Scale is in kb. 


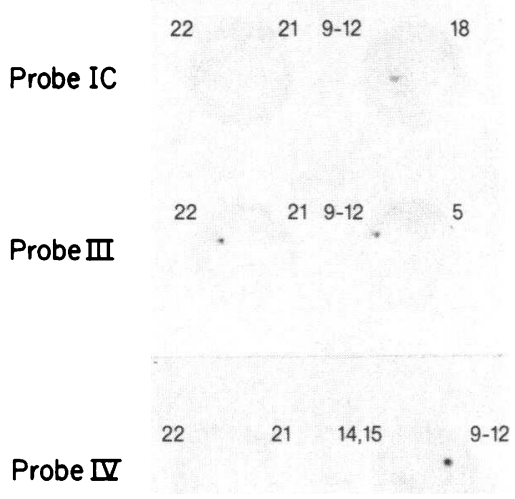

are shown. The probes
employed are indicated at the left of the corresponding pair of filters.

chromosome 12 (Fig. 3, $A$ and $B$ ). Total human genomic DNA and DNA from the hybrid cell line was digested with restriction enzymes for agarose gel electrophoresis and Southern blotting with cDNA probe III. Bands detected in both the human $(\mathrm{H})$ and mouse-human hybrid $(\mathrm{M})$ digests were assigned to human chromosome 12. Bands detected only in total human genomic DNA $(\mathrm{H})$ are labeled with arrows in Fig. 3 and are presumed to have originated from chromosome 22 . The assignment to chromosome 22 of two bands detected in Sst I digests of human genomic DNA (Fig. $3 \mathrm{~B}$ ) was confirmed by their detection in DNA from purified flow-sorted human chromosome 22 (Fig. 3
$C)$. In addition, the assignment of the bands indicated by arrows in Fig. $3 \mathrm{~A}$ to chromosome 22 was confirmed for the enzymes $\mathrm{Bgl}$ II, Hind III, and Nco I by analysis of DNA from a mousehuman hybrid cell line containing only human chromosome 22 (data not shown). The nature of the cross-hybridizing sequences on chromosome 22 is currently under investigation.

The identification of gene deletions in patients with $v W D$. The cDNA probes I-IV were hybridized to Eco RI-digested leukocyte DNA from Italian patients with vWD, including 19 patients with autosomal-dominant vWD (type I) and 19 patients with severe recessive vWD (type III). In many cases parents and siblings of affected individuals were also studied. For all 19 of the patients with vWD type I and for 17 of the patients with vWD type III, the hybridization patterns obtained were indistinguishible from those of normal controls. However, two apparently unrelated patients with vWD (type III), previously identified as C.K. (16) and S.G. $(32,33)$, were found to have large deletions of the vWF gene (Fig. 4). The parents of patient S.G. were first cousins, so it is likely that he is homozygous for a single type of defect. The extent of deletion may be different for each of the mutant alleles of patient C.K. A total of 25 or 26 bands was detected with probes I-IV in DNA from normal controls and unaffected relatives, compared with only five or six bands in DNA from S.G. or C.K., respectively.

The heterozygous parents of C.K. and S.G. are expected to have half of the hybridizing DNA of normal controls. Such a gene dosage effect is not uniformly apparent in Fig. 4, reflecting the difficulty in quantifying gene dosage by the unstandardized
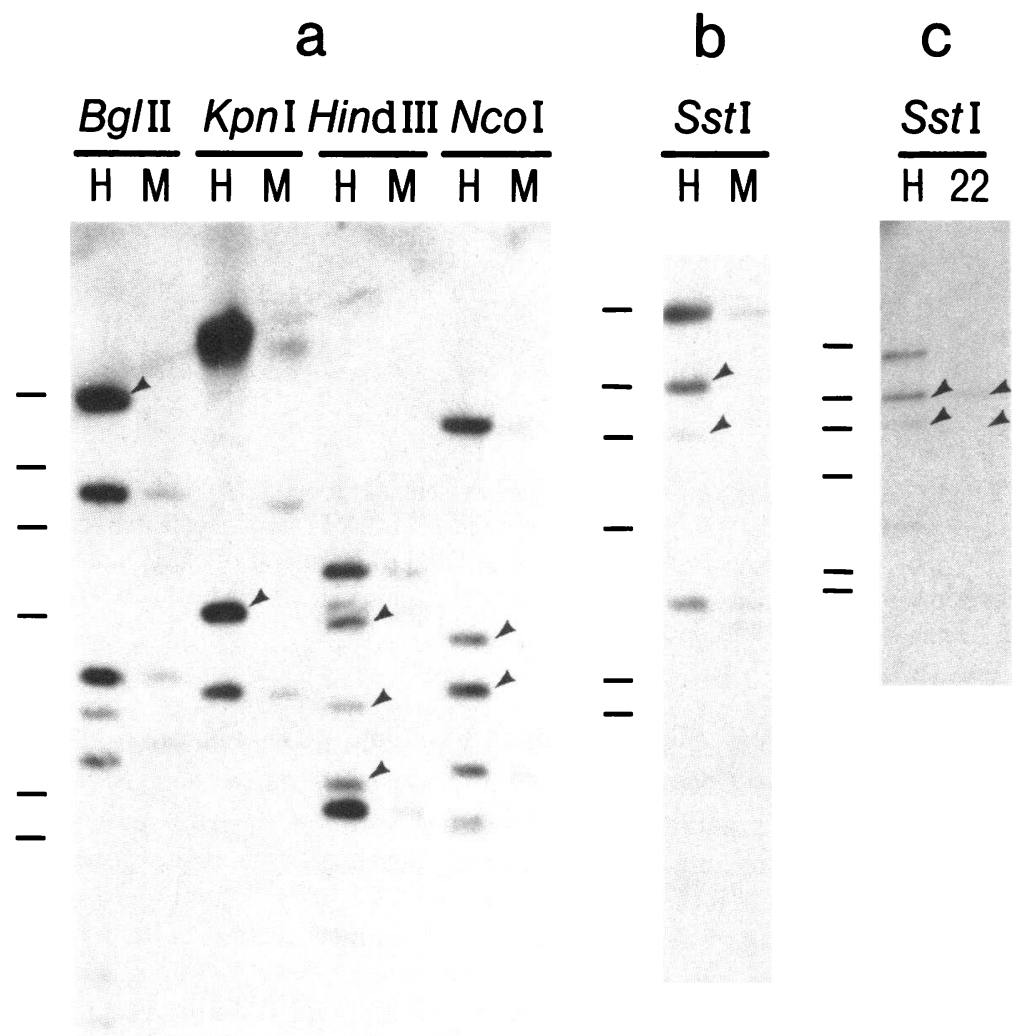

Figure 3. Hybridization of probe III to human genomic DNA and DNA from a mouse-human hybrid cell line containing human chromosome 12 . Normal human genomic DNA $(H)$, DNA from a mouse-human hybrid cell line that contains human chromosome 12 but not human chromosomes $9-11$ or $22(M)$, or DNA from purified human chromosome 22 (22) was digested with the indicated restriction enzymes and subjected to agarose gel electrophoresis for Southern blotting. The mobility of Hind III fragments of phage lambda DNA is indicated at the left of each blot in descending order: 23.1, 9.4, 6.6, 4.4, 2.3, and $2.0 \mathrm{~kb}$. Arrows indicate bands that are attributed to human chromosome 22 because they are present in total human genomic DNA but absent in DNA from the hybrid cell line. 
A

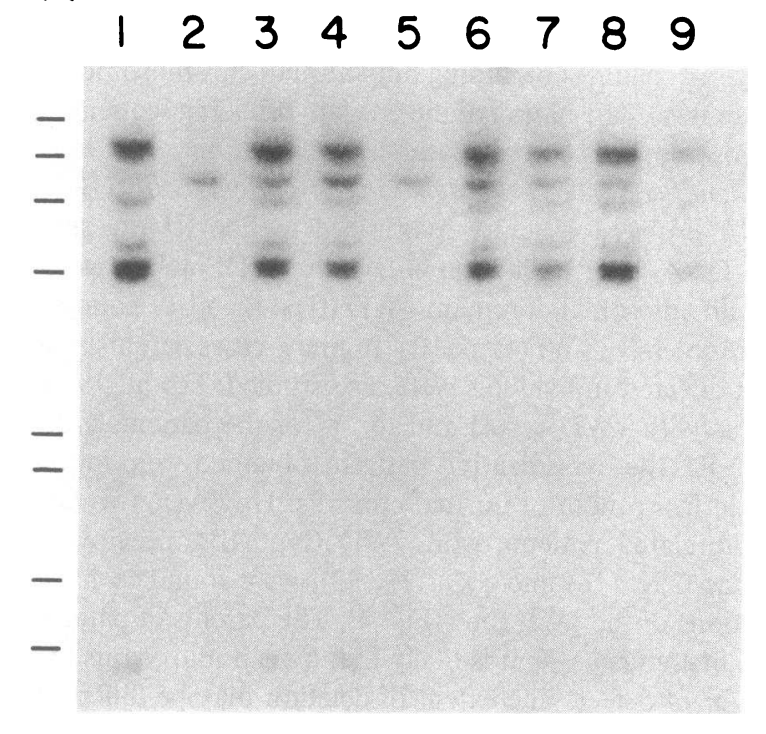

B
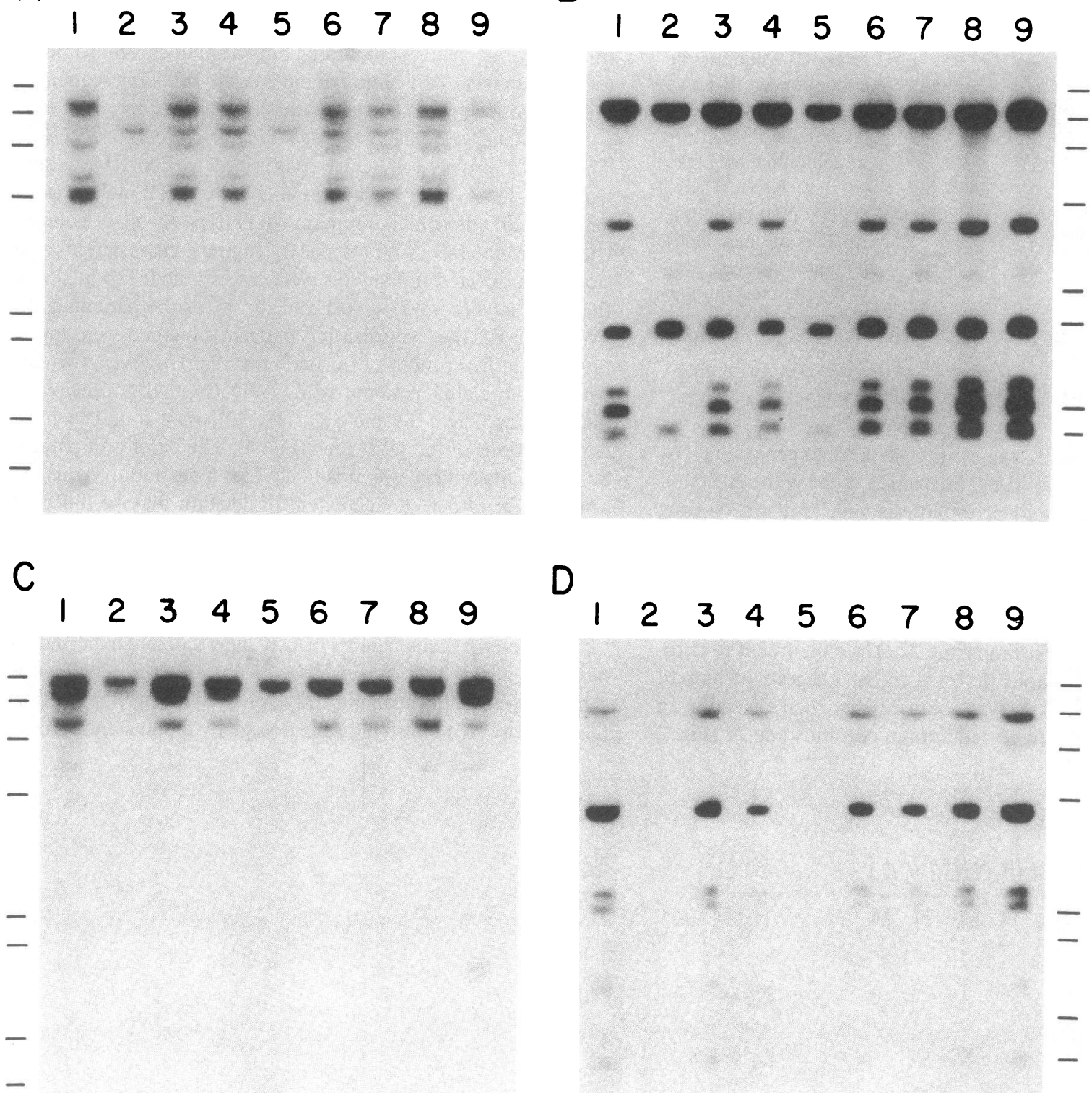

D

Figure 4. Southern blots of genomic DNA digested with Eco RI and hybridized with vWF cDNA probes. In each panel the samples are: (lane 1) a normal control, (lane 2) patient C.K., (lane 3) father of C.K., (lane 4) mother of C.K., (lane 5) patient S.G., (lane 6) father of S.G., (lane 7) mother of S.G., (lane 8) sister of S.G., (lane 9) a normal

blotting method employed. Accordingly, some gene deletions in the additional 36 patients studied may not have been detected.

The extent of $v W F$ gene deletion in patients S.G. and C.K. A single band of $8.4 \mathrm{~kb}$ was detected with probe I in the DNA of both patient C.K. and S.G. (Fig. $4 \mathrm{~A}$ ). The origin of this band was investigated with subfragments of probe $I$. The same band was detected in both patients and control DNA with probe IA, whereas neither patient exhibited any of the three bands detected in control DNA with probe IB (Fig. 5), nor the 6.8-kb and 0.9$\mathrm{kb}$ bands detected with probe IC (data not shown). The relative intensity of the hybridization signal for patient C.K. appears reduced in Fig. $5 A$, but in other blots it is identical to normal controls (data not shown). The chromosome localization of this 8.4-kb band is not known. Thus, both patients appear to have control. The vWF cDNA probes were: $(A)$ probe I, $(B)$ probe II, $(C)$ probe III, $(D)$ probe IV. The mobility of DNA standards is marked on each panel in descending order: Hind III fragments of phage lambda DNA, 23.1, 9.4, 6.6, 4.4, 2.3, and $2.0 \mathrm{~kb}$; Hae III fragments of $\Phi \times 174$ DNA, 1.35 and $1.1 \mathrm{~kb}$.

suffered deletions on both alleles with similar boundaries at the $5^{\prime}$ end of the vWF gene. The two families have been geographically separated in the north and south of Italy for many generations and appear to be truly unrelated. We cannot formally prove that the genetic lesions in C.K. and S.G. are independent without more detailed structural characterization of the mutant genes.

The DNA from patients C.K. and G.S. did not hybridize to probe IB (Fig. $5 B$ ) or probe IV (Fig. $4 \mathrm{D}$ ), indicating that the corresponding segments of the vWF gene had been deleted. The intervening DNA on chromosome 12 that corresponds to probes II and III should be deleted as well. We cannot exclude the possibility that a band from the vWF locus might be present, however that would require two separate deletion events in the 

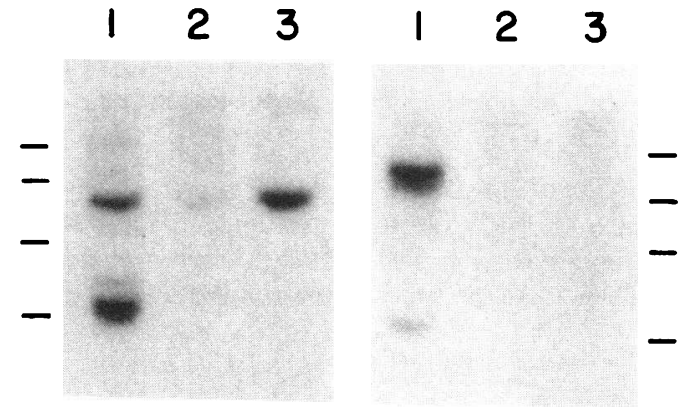

Figure 5. Southern blots of Eco RI digests of genomic DNA hybridized to subfragments of probe I. Blotting conditions were as described in the legend to Fig. 2. In each panel the samples are: (lane I) a normal control, (lane 2) patient C.K., (lane 3) patient S.G. The mobility of Hind III fragments of phage lambda DNA is noted as in Fig. 2. Probes employed were (left) probe IA and (right) probe IB. Patients failed to hybridize with probe IB, however an $8.4-\mathrm{kb}$ band was detected with probe IA.

vWF gene of both families, which seems very unlikely. The five or six bands detected by probes II and III for these patients (Fig. $4, B$ and $C$ ) are consistent with their localization to chromosome 22, not to the vWF locus. This has been confirmed directly by examination of Eco RI-digested DNA from a mouse-human hybrid cell line that contains only human chromosome 22 . However, these data do not exclude the possibility that fragments of the same mobility might be derived from both chromosome 12 and chromosome 22. In fact, the $12.1-\mathrm{kb}$ and $1.15-\mathrm{kb}$ bands detected with probe II (Fig. $4 \mathrm{~B}$ ), and the $15.5-\mathrm{kb}$ band detected with probe III (Fig. $4 C$ ) are present in DNA prepared from mouse-human hybrid cells containing either human chromosome 12 or 22, suggesting that both loci contain homologous Eco RI fragments of similar size (data not shown). Probe III reveals a potential polymorphism at the chromosome 22 locus. The normal controls, patient C.K. and her relatives, exhibit a pair of bands at 15.5 and $11.5 \mathrm{~kb}$, whereas patient S.G. and his relatives show only the band at $15.5 \mathrm{~kb}$ (Fig. $4 C$ ). Probe III also detects a band at $1.85 \mathrm{~kb}$ in some controls but in no patients or relatives. This band cannot yet be assigned to a specific chromosome.

The simplest interpretation of these data is that both C.K. and G.S. have large deletions in both $\mathrm{vWF}$ alleles corresponding to at least the $3^{\prime}-7.4 \mathrm{~kb}$ of the vWF cDNA. Over $60 \mathrm{~kb}$ of genomic DNA have been partially characterized that encode the cDNA of probes III and IV (34). Another $\sim 60 \mathrm{~kb}$ of Eco RI bands on chromosome 12 was detected by probes I and II (Table I). Thus the vWF gene spans at least $\sim 120 \mathrm{~kb}$, and the size of these deletions probably exceeds $110 \mathrm{~kb}$ in both patients.

\section{Discussion}

We have demonstrated that fragments of the vWF cDNA hybridize not only to the vWF locus on chromosome 12 but also to sequences on chromosome 22 . The conditions of hybridization were very stringent, so that the cross-hybridizing locus should be highly homologous to vWF. In fact, several of the Eco RI fragments detected with probes II and III are of similar or identical size from both the chromosome 12 and chromosome 22 loci. The 5'-and 3'-boundaries of the cDNA segment responsible
Table I. Eco RI Bands Identified in Normal and $v W D$ DNA

\begin{tabular}{|c|c|c|c|c|c|c|c|}
\hline \multirow[b]{2}{*}{ Probe } & \multicolumn{5}{|c|}{ DNA from } & \multirow[b]{2}{*}{ Eco RI bands } & \multirow{2}{*}{$\begin{array}{l}\text { Chromosome } \\
\text { localization }\end{array}$} \\
\hline & $\mathbf{N}$ & C.K. & CKR & S.G. & SGR & & \\
\hline & & & & & & $k b$ & \\
\hline \multirow[t]{8}{*}{ I } & + & - & + & - & + & $9.7^{*}$ & 12 \\
\hline & + & - & + & - & + & $9.6^{*}$ & 12 \\
\hline & + & + & + & + & + & $8.4^{\ddagger}$ & $12 ?$ \\
\hline & + & - & + & - & + & $6.8^{8}$ & 12 \\
\hline & + & - & + & - & + & $5.1^{\ddagger}$ & 12 \\
\hline & + & - & + & - & + & $4.4^{\ddagger}$ & 12 \\
\hline & + & - & + & - & + & $4.3^{* \neq}$ & 12 \\
\hline & + & - & + & - & + & $0.90^{5}$ & 12 \\
\hline \multirow[t]{6}{*}{ II } & + & + & + & + & + & 12.1 & $12 / 22$ \\
\hline & + & - & + & - & + & 3.5 & 12 \\
\hline & + & + & + & + & + & 2.0 & 22 \\
\hline & + & - & + & - & + & 1.5 & 12 \\
\hline & + & - & + & - & + & 1.35 & 12 \\
\hline & + & + & + & + & + & 1.15 & $12 / 22$ \\
\hline \multirow[t]{5}{*}{ III } & + & + & + & + & + & 15.5 & $12 / 22$ \\
\hline & + & + & + & - & - & 11.5 & 22 \\
\hline & + & - & + & - & + & 7.5 & 12 \\
\hline & + & - & + & - & + & 5.3 & 12 \\
\hline & \pm & - & - & - & - & 1.85 & NA \\
\hline \multirow[t]{7}{*}{ IV } & + & - & + & - & + & 9.4 & 12 \\
\hline & + & - & + & - & + & 7.2 & 12 \\
\hline & + & - & + & - & + & 4.1 & 12 \\
\hline & + & - & + & - & + & 2.7 & 12 \\
\hline & + & - & + & - & + & 2.4 & 12 \\
\hline & + & - & + & - & + & 1.65 & 12 \\
\hline & + & - & + & - & + & 1.1 & 12 \\
\hline
\end{tabular}

The entries $(+/-)$ represent the presence or absence of bands with the indicated size in samples of DNA from normal controls $(\mathrm{N})$, patient C.K., unaffected relatives of C.K. (CKR), patient S.G., and unaffected relatives of S.G. (SGR). Bands detected with subfragments of probe I are indicated by ${ }^{*}$ if detected with probe IB, ${ }^{*}$ if detected with probe IA, and ${ }^{\S}$ if detected with probe IC. Bands present in both families and normal controls but absent from both patients were assigned to the vWF locus on chromosome 12. Bands present in DNA from either patient that were detected with probes II and III were assigned to chromosome 22. NA, not assigned. The 12.1-kb and 1.15-kb bands detected with probe II and the $15.5-\mathrm{kb}$ band detected with probe III were assigned to both chromosomes 12 and 22 , as described in the text. The faint band between the 2.0-kb and 3.5-kb bands detected with probe II (Fig. $4 B$ ) is not consistently visible and may represent partial digestion of a fragment from chromosome 22 . The apparently polymorphic band at $1.85 \mathrm{~kb}$ detected with probe III in some normal controls could not be assigned to a specific locus.

for this cross-hybridization have not been defined precisely, but must lie between probes IC and IV (Fig. 1). The 3'-boundary probably lies between the second and third Nco I sites of probe III, because probes from the $3^{\prime}-3 \mathbf{k b}$ of the cDNA have been reported to hybridize only to chromosome 12 (9). The cDNA sequence between probe IC and the last Nco I site of probe III encodes the triplicated A domains of VWF (8). A tryptic fragment of vWF containing the first two A domains possesses a binding 
site for platelet glycoprotein Ib (35), raising the possibility that an A-like domain might be employed in another protein for a similar binding function. Sequences that appear to be homologous to the A domains of vWF have been identified in complement factor B and possibly in complement component C2 $(12,15)$. However, the genes for these proteins are on chromosome 6 (36).

The identification of gene deletion in two patients with vWD provides the first definitive proof that at least some forms of vWD are actually caused by lesions in the vWF gene. The two patients described in this report with severe vWD due to gene deletions have high-titer precipitating alloantibodies to transfused vWF, and neither has detectable endogenous plasma vWF (16, $32,33)$. All other patients studied showed normal hybridization patterns with all four cDNA probes and also exhibited immune tolerance to vWF. The hypothesis has been advanced that antibodies should develop in patients with large gene deletions who can make no recognizable vWF at all (16), and this is consistent with our findings. Four affected siblings with severe vWD from a third kindred have recently been found to have a more extensive deletion of the vWF gene, and three of the four patients received multiple infusions of VWF and had developed alloantibodies to it (37).

The interplay between specific alterations in gene structure, exposure to the exogenous gene product by transfusion, and the host immune system is not fully understood. Failure to express any protein epitope might be sufficient to elicit antibodies to that epitope in a patient with the appropriate immune responsiveness. In this regard, certain kinds of genetic lesions could be more effective than others in preventing the expression of protein antigens. For example, frameshift or nonsense mutations might be suppressed sufficiently in some persons to allow the synthesis of a limited amount of normal protein and the establishment of immune tolerance. Clearly, such mechanisms could not compensate for the deletion of protein coding sequences from a gene. However, despite the occurrence of a gene deletion, some individuals might be unable to recognize the corresponding protein antigens as foreign, even though the antigens are not produced endogenously, because of inherited or acquired features of their immune response. Given the complexity of the immune system, it is not surprising that there is variability in the relationship between genetic lesions and the occurrence of alloantibodies to the gene product. In hemophilia A, no consistent pattern has been discerned between the development of alloantibodies to factor VIII and mutations in the factor VIII gene $(22,23)$, whereas in hemophilia B, there is to date an excellent concordance between antibodies to factor IX and large deletions in the factor IX gene (18-21). As suggested by Giannelli and Brownlee (21), determination of the epitope specificity of alloantibodies to factor VIII, factor IX, and vWF should help us to understand these observations.

\section{Acknowledgments}

We wish to thank Dr. F. Baudo (Milano), Dr. V. Carnelli (Milano), Dr. G. Mariani (Roma), Dr. F. Panicucci (Pisa), Mr. T. Ripa (Bari), and Dr. F. Rodeghiero (Vicenza) for providing samples of blood from their patients with von Willebrand disease. We also wish to thank Dr. David Cox for the mouse-human hybrid cell line containing human chromosome 12, Dr. Frank Ruddle for the mouse-human hybrid cell line containing human chromosome 22, and Dr. Yuet Wai Kan for encouragement and helpful discussions.
This work was supported in part by grants from Consiglio Nazionale della Ricerche, Progetto Finalizzato Ingegneria Genetica e Basi Molecolari delle Malattie Ereditarie, and from Fondazione A. Bianchi Bonomi.

Note added in proof: The 8.4-kb band detected with probe I (Fig. 4 $A$ ) and probe IA (Fig. $5 \mathrm{~A}$ ) may be due to 53 nucleotides at the $5^{\prime}$ end of these probes that appear to be unrelated to VWF. Thus, the deletions in both patients C.K. and S.G. probably encompass the entire VWF gene.

\section{References}

1. Holmberg, L., and I. M. Nilsson. 1985. von Willebrand disease. Clin. Haematol. 14:461-488.

2. Tuddenham, E. G. D., R. S. Lane, F. Rotblat, A. J. Johnson, T. J. Snape, S. Middleton, and P. B. A. Kernoff. 1982. Response to infusions of polyelectrolyte fractionated human factor VIII concentrate in human hemophilia A and von Willebrand's disease. Br. J. Haematol. 52:259-267.

3. Hoyer, L. W. 1981. The factor VIII complex: structure and function. Blood. 58:1-13.

4. Jaffe, E. A., L. W. Hoyer, and R. L. Nachman. 1973. Synthesis of antihemophilic factor antigen by cultured human endothelial cells. $J$. Clin. Invest. 52:2757-2764.

5. Jaffe, E. A., L. W. Hoyer, and R. L. Nachman. 1974. Synthesis of von Willebrand factor by cultured human endothelial cells. Proc. Natl. Acad. Sci. USA. 71:1906-1909.

6. Nachman, R. L., R. Levine, and E. A. Jaffe. 1977. Synthesis of factor VIII antigen by cultured guinea pig megakaryocytes. J. Clin. Invest. 60:914-921.

7. Titani, K., S. Kumar, K. Takio, L. H. Ericsson, R. D. Wade, K. Ashida, K. A. Walsh, M. W. Chopek, J. E. Sadler, and K. Fujikawa. 1986. Amino acid sequence of human von Willebrand factor. Biochemistry. 25:3171-3184.

8. Sadler, J. E., B. B. Shelton-Inloes, J. M. Sorace, J. M. Harlan, K. Titani, and E. W. Davie. 1985. Cloning and characterization of two cDNAs coding for human von Willebrand factor. Proc. Natl. Acad. Sci. USA. 82:6394-6398.

9. Ginsburg, D. R., R. I. Handin, D. T. Bonthron, T. A. Donlon, G. A. P. Bruns, S. A. Latt, and S. H. Orkin. 1985. Human von Willebrand factor (vWF): isolation of complementary DNA (cDNA) clones and chromosomal localization. Science (Wash. DC). 228:1401-1406.

10. Lynch, D. C., T. S. Zimmerman, C. J. Collins, M. Brown, M. J. Morin, E. H. Ling, and D. M. Livingston. 1985. Molecular cloning of cDNA for human von Willebrand factor: authentication by a new method. Cell. 41:49-56.

11. Verweij, C. L., C. J. M. de Vries, B. Distel, A.-J. van Zonneveld, A. G. van Kessel, J. A. van Mourik, and H. Pannekoek. 1985. Construction of cDNA coding for human von Willebrand factor using antibody probes for colony-screening and mapping of the chromosomal gene. $\mathrm{Nu}$ cleic Acids Res. 13:4699-4717.

12. Shelton-Inloes, B. B., K. Titani, and J. E. Sadler. 1986. cDNA sequences for human von Willebrand factor reveal five types of repeated domains and five possible protein sequence polymorphisms. Biochemistry. 25:3164-3170.

13. Fay, J. P., Y. Kawai, D. D. Wagner, D. Ginsburg, D. Bonthron, B. M. Ohlsson-Wilhelm, S. I. Chavin, G. N. Abraham, R. I. Handin, S. H. Orkin, R. R. Montgomery, and V. J. Marder. 1986. Propolypeptide of von Willebrand factor circulates in blood and is identical to von Willebrand antigen II. Science (Wash. DC). 232:995-998.

14. Verweij, C. L., P. J. Diergaarde, M. Hart, and H. Pannekoek. 1986. Full-length von Willebrand factor (vWF) cDNA encodes a highly repetitive protein considerably larger than the mature vWF subunit. EMBO (Eur. Mol. Biol. Organ.) J. 5:1839-1847.

15. Sadler, J. E., B. B. Shelton-Inloes, J. M. Sorace, and K. Titani. 1986. Cloning of cDNA and genomic DNA for human von Willebrand factor. Cold Spring Harbor Symp. Quant. Biol. In press. 
16. Mannucci, P. M., and D. Mari. 1984. Antibodies to factor VIIIvon Willebrand factor in congenital and acquired von Willebrand's disease. In Factor VIII Inhibitors. L. W. Hoyer, editor. Alan R. Liss, Inc., New York. 109-122.

17. Shapiro, S. S. 1979. Antibodies to blood coagulation factors. Clin. Haematol. 8:207-214.

18. Giannelli, F., K. H. Choo, D. J. G. Rees, Y. Boyd, C. R. Rizza, and G. G. Brownlee. 1983. Gene deletions in patients with haemophilia $B$ and anti-factor IX antibodies. Nature (Lond.). 303:181-182.

19. Peake, I. R., B. L. Furlong, and A. L. Bloom. 1984. Carrier detection by direct gene analysis in a family with haemophilia B (factor IX deficiency). Lancet. i:242-243.

20. Bernardi, F., L. Del Senno, R. Barbieri, D. Buzzoni, R. Gambari, G. Marchetti, F. Conconi, F. Panicucci, M. Positano, and S. Pitruzzello. 1985. Gene deletion in an Italian haemophilia B subject. J. Med. Genet. 22:305-307.

21. Giannelli, F., and G. G. Brownlee. 1986. Cause of the 'inhibitor' phenotype in the haemophilias. Nature (Lond.). 320:196.

22. Gitschier, J., W. I. Wood, E. G. D. Tuddenham, M. A. Shuman, T. M. Goralka, E. Y. Chen, and R. M. Lawn. 1985. Detection and sequence of mutations in the factor VIII gene of haemophiliacs. Nature (Lond.). 315:427-430.

23. Antonarakis, S. E., P. G. Waber, S. D. Kittur, A. S. Patel, H. H. Kazazian, Jr., M. A. Mellis, R. B. Counts, G. Stamatoyannopoulos, E. J. W. Bowie, D. N. Fass, D. D. Pittman, J. M. Wozney, and J. J. Toole. 1985. Hemophilia A. Detection of molecular defects and carriers by DNA analysis. $N$. Engl. J. Med. 313:842-848.

24. Yanisch-Perron, C., J. Vieira, and J. Messing. 1985. Improved M13 phage cloning vectors and host strains: nucleotide sequences of the M13mp18 and pUC19 vectors. Gene (Amst.). 33:103-119.

25. Maniatis, T., E. F. Fritsch, and J. Sambrook. 1982. Molecular Cloning: A Laboratory Manual. Cold Spring Harbor Laboratory, New York. 109-178.

26. Feinberg, A. P., and B. Vogelstein. 1983. A technique for radiolabelling DNA restriction endonuclease fragments to high specific activity. Anal. Biochem. 132:6-10.

27. Lebo, R. V., F. Gorin, R. J. Fletterick, F. T. Kao, M. C. Cheung,
B. D. Bruce, and Y. W. Kan. 1984. High-resolution chromosome sorting and DNA spot-blot analysis assign McArdle's syndrome to chromosome 11. Science (Wash. DC). 225:57-59.

28. Grunebaum, L., J.-P. Cazenave, G. Camerino, C. Kloepfer, J.-L. Mandel, P. Tolstoshev, M. Jaye, H. De la Salle, and J.-P. Lecocq. 1984. Carrier detection of hemophilia B by using restriction site polymorphism associated with the coagulation factor IX gene. J. Clin. Invest. 73:1491-1495.

29. Kapuściński, J., and B. Skoczylas. 1977. Simple and rapid fluorimetric method for DNA microassay. Anal. Biochem. 83:252-257.

30. Kapuściński, J., and K. Yanagi. 1979. Selective staining by 4',6diamidine-2-phenylindole of nanogram quantities of DNA in the presence of RNA on gels. Nucleic Acids Res. 6:3535-3542.

31. Chomczynski, P., and P. K. Qasba. 1984. Alkaline transfer of DNA to plastic membrane. Biochem. Biophys. Res. Commun. 122:340344.

32. Mannucci, P. M., D. Meyer, Z. M. Ruggeri, J. Koutts, N. Ciavarella, and J.-M. Lavergne. 1976. Precipitating antibodies in von Willebrand's disease. Nature (Lond.). 262:141-142.

33. Ruggeri, Z. M., N. Ciavarella, P. M. Mannucci, A. Molinari, F. Dammacco, J. M. Lavergne, and D. Meyer. 1979. Familial incidence of precipitating antibodies in von Willebrand's disease: a study of four cases. J. Lab. Clin. Med. 94:60-74.

34. Sorace, J. M., B. B. Shelton-Inloes, and J. E. Sadler. 1986. Isolation and characterization of genomic clones for human von Willebrand factor. Fed. Proc. 45:1639.

35. Fujimura, Y., K. Titani, L. Z. Holland, S. R. Russell, J. R. Roberts, J. H. Elder, Z. M. Ruggeri, and T. S. Zimmerman. 1986. Von Willebrand factor. A reduced and alkylated 52/48-kDA fragment beginning at amino acid residue $\mathbf{4 4 9}$ contains the domain interacting with platelet glycoprotein Ib. J. Biol. Chem. 261:381-385.

36. Campbell, R. D., D. R. Bentley, and B. J. Morley. 1984. The factor B and C2 genes. Philos. Trans. R. Soc. Lond. B Biol. Sci. 306: 367-378.

37. Ngo, K.-Y., D. Lynch, J. Gitschier, N. Ciavarella, Z. M. Ruggeri, and T. S. Zimmerman. 1986. Gene deletion in four patients from the same kindred with severe von Willebrand disease and anti-von Willebrand factor antibodies. Blood. 68(Suppl. 1):339a. 